\title{
Co-expression of E- and P-cadherin in breast cancer: role as an invasion suppressor or as an invasion promoter?
}

\author{
Ana S Ribeiro ${ }^{1 *}$, Laura C Carreto², André Albergaria', Bárbara Sousa', Sara Ricardo ${ }^{1}$, Fernanda Milanezi', \\ Raquel Seruca ${ }^{1}$, Manuel A Santos ${ }^{2}$, Fernando Schmitt ${ }^{1,3}$, Joana Paredes ${ }^{1}$ \\ From 16th International Charles Heidelberger Symposium on Cancer Research \\ Coimbra, Portugal. 26-28 September 2010
}

Cadherins are cell-cell adhesion molecules. During tumor progression, their expression and/or function are frequently altered. E-cadherin down-regulation is often associated with tumor initiation and progression in breast cancer [1], whereas P-cadherin overexpression is associated with a worse patient survival [2] and with invasive breast cancer cells [3].

In this study, we aimed to understand if P-cadherin overexpression could interfere with E-cadherin invasion suppressor role in breast cancer.

Therefore, E- and P-cadherin expression was evaluated in a series of invasive breast carcinomas. P-cadherin overexpressing tumors often do not loose E-cadherin and tumors co-expressing both cadherins showed a more aggressive behavior and were related with the worst patient survival. Further, we performed in vitro studies by silencing both cadherins in BT-20 breast cancer cells. Eand P-cadherin co-expressing breast cancer cells showed increased cell invasion and migration capacities, when compared with the ones expressing only one cadherin. $\mathrm{P}$-cadherin silencing led to increased levels of cell death, demonstrating it as a cancer cell survival signal. Also, microarrays of BT-20 cells, after E- and/or P-cadherin silencing, showed that the role of each cadherin alone is distinct from when these are co-expressed in the same cell, conferring different transcriptional programs.

We can conclude that E- and P-cadherin co-expression has an invasion promoter role in breast cancer cells and is a poor patient prognostic biomarker.

\footnotetext{
* Correspondence: aribeiro@ipatimup.pt

'IPATIMUP, Institute of Molecular Pathology and Immunology of the University of Porto, Porto, Portugal

Full list of author information is available at the end of the article
}

\section{Author details}

'IPATIMUP, Institute of Molecular Pathology and Immunology of the University of Porto, Porto, Portugal. ${ }^{2}$ Department of Biology and CESAM, University of Aveiro, Aveiro, Portugal. ${ }^{3}$ Medical Faculty of the University of Porto, Porto, Portugal.

Published: 24 September 2010

\section{References}

1. Cowin P, Rowlands TM, Hatsell SJ: Cadherins and catenins in breast cancer. Curr Opin Cell Biol 2005, 17:499-508.

2. Paredes J, Albergaria A, Oliveira JT, Jerónimo C, Milanezi F, Schmitt FC: P-cadherin overexpression is an indicator of clinical outcome in invasive breast carcinomas and is associated with $\mathrm{CDH} 3$ promoter hypomethylation. Clin Cancer Res 2005, 11:5869-5877.

3. Paredes J, Stove C, Stove V, Milanezi F, Van Marck V, Derycke L, Mareel M, Bracke M, Schmitt F: P-cadherin is up-regulated by the antiestrogen ICI 182,780 and promotes invasion of human breast cancer cells. Cancer Res 2004, 64:8309-8317.

doi:10.1016/j.ceb.2005.08.014

Cite this article as: Ribeiro et al: Co-expression of E- and P-cadherin in breast cancer: role as an invasion suppressor or as an invasion promoter?. BMC Proceedings 2010 4(Suppl 2):P47.
Submit your next manuscript to BioMed Central and take full advantage of:

- Convenient online submission

- Thorough peer review

- No space constraints or color figure charges

- Immediate publication on acceptance

- Inclusion in PubMed, CAS, Scopus and Google Scholar

- Research which is freely available for redistribution

Submit your manuscript at www.biomedcentral.com/submit
Biomed Central 